Sign Systems Studies 30.1, 2002

\title{
A sign is not alive - a text is
}

\author{
Kalevi Kull \\ Department of Semiotics, University of Tartu \\ Tiigi Str. 78, Tartu, Estonia \\ e-mail:kalevi@zbi.ee
}

\begin{abstract}
The article deals with the relationships between the concepts of life process and sign process, arguing against the simplified equation of these concepts. Assuming that organism (and its particular case - cell) is the carrier of what is called 'life', we attempt to find a correspondent notion in semiotics that can be equalled to the feature of being alive. A candidate for this is the textual process as a multiple sign action. Considering that biological texts are generally non-linguistic, the concept of biotext should be used instead of 'text' in biology.
\end{abstract}

If we put together many branches and great quantity of leaves, we still cannot understand the forest. But if we know how to walk through the forest of culture with our eyes open, confidently following the numerous paths which criss-cross it, not only shall we be able to understand better the vastness and complexity of the forest, but we shall also be able to discover the nature of the leaves and branches of every single tree.

U. Eco (1990: xiii)

In this note I would like to pay attention to the importance of nonoversimplification in applications of semiotic concepts in biology. This infers from the threshold of the type of diversity (the categorised 
diversity) that the contemporary biology describes as characteristic to all living systems.

There is not only Floyd Merrell, who has written about "the Life $\approx$ Signs equation" (Merrell 1996: 315n1). ${ }^{1}$ Particularly in that part of semiotics which is strongly influenced by Peircean ideas, the expressions like 'living signs' have become quite frequent in recent years. Another factor behind these claims is the influence of biosemiotic studies, including its basic assumption that semiosis and life are coextensive. ${ }^{2}$ That the issue is not of secondary importance for semiotics, is evident from Thomas A. Sebeok's statements:

I postulate that two cardinal and reciprocal axioms of semiotics - subject, as always, to falsication - are: (1a) The criterial mark of all life is semiosis; and (1b) Semiosis presupposes life. [...] Further semiosic unfoldings — such as the genesis of ordered oppositions like self/other, inside/outside, and so forth - derive from, or are corollaries of, the above pair of universal laws. (Sebeok 2001: 10-11)

The idea about the identity of life and semiosis, no doubt, has been a productive core hypothesis, considerably assisting in the attempts to find a correspondence between biology and semiotics. In a more detailed analysis, a question arises, whether biology itself can learn anything from these ideas; e.g., whether it may be possible to give a more profound description to the concept of life using its semiotic features.

The claims above can be easily interpreted as if a sign, being an element of life, is itself alive. Still, one has to keep in mind that the problem of elements in sign science is very different from the problem of elements in chemistry.

A discussion about the relationship between the concepts of 'life' and 'sign' is complicated due to the fuzziness of the 'life' concept altogether. A collection of life definitions provided by Barbieri (2001: 235-242) perfectly demonstrates the diversity of these definitions. However, the problem is inescapable for biology, and I suggest that a semiotic approach will be very helpful in achieving a more clear understanding (if not a solution) of it. ${ }^{3}$

\footnotetext{
${ }^{1}$ See also Merrell 1992, 1994, 1998, 1999.

${ }^{2}$ See Deely 1992 on a discussion of this statement.

${ }^{3}$ The problem of defining life as a semiotic phenomenon has been extensively analysed by Emmeche (1998, 2000).
} 


\section{Biotext}

Sign, however an absolutely necessary element of any semiotic system, still cannot be taken as a fundamental semiotic unit, because sign cannot exist as a single sign - sign is always a part of a bigger system, sign is always accompanied by another sign(s). This is not because signs always just happen to be placed not far from each other and in multitude, but because it belongs to the very nature of sign to be 'a part of', to be a meron. ${ }^{4}$ At least in some traditions in semiotics, this bigger system can be called 'text'.

Comparing the above statement (that sign cannot exist as a single sign), by analogy, to a biological key idea that the minimal living unit is cell, one may conclude that the same should be applicable here 'cell cannot exist as a single cell'. However, this comparison is not exact, and not true. Because, the cell, on the one hand, being "the simplest entity to possess real semiotic competence" (Hoffmeyer 1997: 940), on the other hand always includes a whole multitude of signs.

This contradiction can be solved if to speak on 'semiosis' instead of 'sign' (as actually is the case in most biosemiotic writings): cell is a minimal semiosic unit. ${ }^{5}$

Semiosis is - according to its common definition - the action of signs, the sign process. "According to Peirce, semiose is a continuous process that is based on the interpretation of one sign through another. Jakobson described this process as translation" (Krampen et al. 1987: 244). Since semiosis is not an action of just one sign, since semiosis involves always a multitude of signs, it is a textual process like translation is. In this way, it has to be concluded that semiosis is not an action of a sign, but an action of signs, and accordingly a more complex structure than that of a single sign has to be present in a simplest semiosic system. If to call this text, one should consider that

\footnotetext{
${ }^{4}$ On the biological interpretation of this statement, see Kull 2000, Emmeche 2002.

5 This, again, raises the problem of intracellular semiosis in prokaryotes. If a closure is required for the minimal semiosic unit, then we still can speak about its parts, merons (and, accordingly, signs), but without a possibility to add a lower level of semiosis. Prokaryotic cell is a minimal organism. In such an interpretation, we can even find a fit to Lotman's view that sign communication assumes the impenetrable elements for which the physical contact becomes insufficient (Lotman 1984: 216).
} 
it may be a non-linguistic text, and therefore it is more proper to call it a biotext.

If so, then the following conclusion becomes necessary - the basic semiosic unit is biotext. Each text is a composition of signs, however, signs are nothing more than functional parts of text that cannot exist without or outside a text.

This can be seen as a reference to a contradiction between the Peircean (or American) and Saussurean (or French, or European) traditions in the development of semiotics throughout the last century. This is a contradiction between 'sign semiotics' and 'text semiotics' (M. Lotman, 2002).

Whether 'text' is a proper term in this status, is of course discussable, because a common interpretation of this term assigns to text the stability, linearity, and fixity. However, e.g., J. Lotman's usage of the term is much more general when he writes, for instance, about "iconic (spatial, non-discrete) texts" (Lotman 1990: 77).

Sign becomes a meaningful entity only due to its relationship to a sign process, semiosis. Accordingly and analogously, text can be seen as a semiotic entity only if a textual process is considered - a text interpretation, a translation in any of its forms.

Thus, in analogy with the term 'semiosis' for sign process, we seem to require a term for text process. On the one hand, this may be a false conclusion, because semiosis always assumes the participation of number of signs, semiosis already is a textual $(s . l$.) process. If single signs can be distinguished, then, in contrary, semiosis never concerns only a single sign. Therefore, it seems that there is no need for an additional term. On the other hand, it is possible to distinguish between semiosis that occurs in particular parts of a text, and the semiosis of the whole text. This is the process in which the whole text, including its multiple codes and levels, in toto, interprets itself. The whole text process, or total interpretation (or perhaps total translation, according to Torop 1995), is what also occurs, for instance, when a new organism is born. 'Giving birth' means that a complete set of conditions and patterns is created ('transferred') that guarantees the independent life for a new organism. This is the same as in case of total translation, when the life of a text can be transferred into the life of a new text. Quite often, the term semiosis has been used in so general meaning that the total text interpretation has also been termed with it. However, it seems to be reasonable — in order to leave less 
place for misunderstandings - to distinguish between semiosis as an 'organ' process, ${ }^{6}$ and 'something else' as an 'organism' process. This 'something else' being equal to - life.

A comparison between the concepts of biological function and sign action (Emmeche 2002) demonstrates that the functional differentiation within a self-referential system is equivalent to the appearance of signs. This is because the functional differentiation means the existence of other-reference. Moreover, "it is the stable integration of self-reference and other-reference which establishes the minimum requirement for an umwelt and thereby sets living systems apart form all their non-living predecessors" (Hoffmeyer 1999: 156). Without functional differentiation there is no signs (like Lotman expresses it in case of identical partners, there is nothing to communicate about). Therefore it is reasonable to say that an organism is always a biotext.

Speaking in this way on semiosis of biotexts, it leads to at least an interesting research program to apply the concepts and tools of holistic biology in text analysis. Several notions, like, e.g., archetype, homology, analogy, etc., are already in use in both areas.

\section{Organism as a self-interpreting biotext}

In case of single (simple) tokens, their recognition is based primarily on the existing categories an interpreting system possesses for signs. Therefore, a token is recognised as a representative of a category, and accordingly, its individuality becomes lost in transmission. Categorisation is a phenomenon that is always accompanying sign processes; it is a precondition of the existence of codes. ${ }^{7}$

In case of compound tokens, their recognition is also a compound process. The particular combination of the element signs in the compound token may be unique, therefore the recognition process can also leave a unique trace.

Since compound token is not the same as a set of signs, one has to ask what turns it into one sign. Another aspect of the nature of the compound signs is that there is more than simply a recognition that occurs in the compound sign interpretation.

${ }^{6}$ It becomes interesting to note here that if there is a correspondence between 'sign' and 'biological function', then 'organs' can be seen as 'categories'.

${ }^{7}$ On the role of categorization, see also Stjernfelt 1992. 


\section{Kalevi Kull}

A remarkable idea of Jakob von Uexküll concerns the distinction between the two kinds of signs - Merkzeichen and Wirkzeichen. ${ }^{8}$ The former ones are related to perceptual categories, whereas for the latter ones the operational (effectual), or motor categorisation takes place. A code between perceptual and operational categories makes it possible for a compound sign to become one whole sign. This occurs if several perceptual categories converge in one operational category. A similar idea has been proposed by Gerald Edelman by his concept of sensomotor categorisation. Mechanism like this means that a principal difference is achieved from just an automatic response to certain factor in environment - this is an ability to recognise individuality. It is a process of interpretation, which, as we saw, requires more than a single sign process - it deals with text (Kull 1998).

Operational categories are the categories of behavioural acts, of body movements, etc. In case of humans, the operational categories can be those of spoken words.

Due to the complex inner structure of organism, consisting in a large number of cells and many tissues, all being in a communicative relationship, there can be the perception-operation cycles that are entirely embedded in the body. This means, inside the body a sequence of perception-operation-perception-operation may include several sequential systems of communication. Accordingly, several levels of categories and categorisation can be developed between the perceptual and the effectual ones. Which means the development of internal texts, the models.

\section{Biosemiotics means biology}

It is appropriate to remind here few formulations by T. A. Sebeok.

The aim of biosemiotics is to extend the notions of general semiotics to encompass the study of semiosis and modeling in all species. The premise which guides biosemiotics is, in fact, that the forms produced by a specific species are constrained by the modeling $\operatorname{system}(s)$ which has evolved from its anatomical constitution. The aim of biosemiotics is to study not only the species belonging to one of the five kingdoms, Monera, Protoctista, Animalia,

${ }^{8}$ Uexküll 1928. It should be mentioned that Uexküll's terms like 'Empfindungsgruppe', 'Gegenstandkerne', etc. (e.g., Uexküll 1907) can be put into correspondence to 'categories' in our sense. 
Plantae, and Fungi, but also to their hierarchically developed component parts, beginning with the cell, the minimal semiosic unit. [...] In a phrase, the target of biosemiotics is the semiosic behavior of all living things. (Sebeok, Danesi 2000: 15)

The basic claim of Sebeok, that the semiosic phenomena begin with the first cell, is certainly consistent with the view of many biologists that cell is the elementary unit of being alive - a fundamental statement in biology since mid 19th century. This also means that the simplest mechanism of sign can be found in a system which has at least the complexity of living cell. ${ }^{9}$

The next statement above says that the sign relationship, which is constituted by a modeling system, evolves from the anatomical constitution of cellular life. I would state it more broadly, using the term morphology instead of anatomy - the morphological units of living systems are semiosic.

In order to understand the nature of organic forms, we need to consider that these forms are very weird if we would like to get them from the mixing of non-living particles. A key to decipher the diversity of organic forms, both the inter-organismal and intra-organismal, is (according to a biosemiotic approach) to look at these as communicative forms, as the forms which are a result of categorisation, of various types. Then, for instance, biological species appear as categories in inter-organismal semiosis, and tissues as categories of intercellular communication within a multicellular organism. These principal objects of biological research being semiosic in their nature, we have to conclude that whole biology unavoidably becomes influenced by the understanding of semiosis.

When looking at biology as a whole, we can recognise a metasemiosic process in it, as represented in Fig. 1 via two capacious triads. It shows morphology and biological systematics as dealing with main intra-organismic and inter-organismic communicative structures, or categories, respectively. Physiology and ecology represent the synchronic, developmental biology and evolutionary biology the diachronic dimensions. However, of course, these can be interpreted also as the three dimensions of sign in the Peircean sense. Or, as a great chain of semiosis with alternating endosemiotic and exosemiotic steps.

\footnotetext{
${ }^{9}$ For an analysis of this statement see Emmeche 2000.
} 

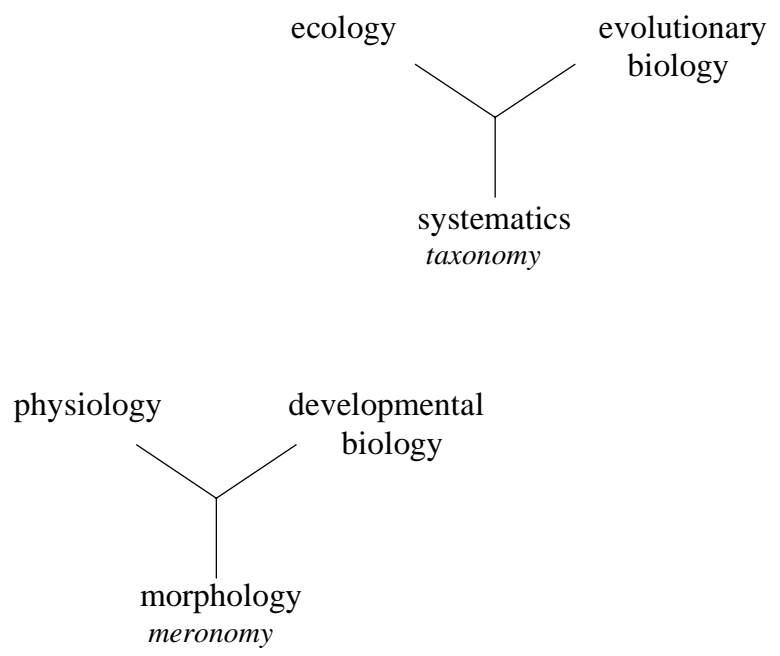

Figure 1. A metasemiosic structure of biology, with endosemiotic (left) and exosemiotic (right) domains.

\section{References}

Barbieri, Marcello 2001. The Organic Codes: The Birth of Semantic Biology. Ancona: PeQuod.

Deely, John 1992. Semiotics and biosemiotics: Are sign-science and life-science coextensive? In: Sebeok, Umiker-Sebeok 1992: 45-75.

Eco, Umberto 1990. Introduction. In: Lotman, Yuri M., Universe of the Mind: A Semiotic Theory of Culture. London: I. B. Tauris, vii-xiii.

Emmeche, Claus 1998. Defining life as a semiotic phenomenon. Cybernetics and Human Knowing 5(1): 3-17.

- 1999. The Sarkar challenge to biosemiotics: Is there any information in a cell? Semiotica 127(1/4): 273-293.

- 2000. Closure, function, emergence, semiosis, and life: The same idea? Reflections on the concrete and the abstract in theoretical biology. Annals of the New York Academy of Sciences 901: 187-197.

- 2001. Does a robot have an Umwelt? Reflections on the qualitative biosemiotics of Jakob von Uexküll. Semiotica 134(1/4): 653-693. 
- 2002. The chicken and the Orphean egg: On the function of meaning and the meaning of function. Sign Systems Studies 30(1): 15-32.

Hoffmeyer, Jesper 1997. The swarming body. In: Rauch, Irmengard; Carr, Gerald F. (eds.), Semiotics Around the World: Synthesis in Diversity. Proceedings of the Fifth Congress of the International Association for Semiotic Studies. Berkeley 1994. Berlin: Mouton de Gruyter, 937-940.

- 1999. The vague boundaries of life. In: Taborsky, Edwina (ed.), Semiosis, Evolution, Energy: Towards a Reconceptualization of the Sign. Aachen: Shaker Verlag, 151-169.

Krampen, Martin; Oehler, Klaus; Posner, Roland; Sebeok, Thomas A.; Uexküll, Thure von 1987. Classics of Semiotics. New York: Plenum Press.

Kull, Kalevi 1998. Organism as a self-reading text: Anticipation and semiosis. International Journal of Computing Anticipatory Systems 1, 93-104.

- 2000. An introduction to phytosemiotics: Semiotic botany and vegetative sign systems. Sign Systems Studies 28: 326-350.

Lotman, Juri 1984. Kultuur ja organism. In: Tiivel, Toomas; Kull, Kalevi; Neuman, Toomas; Sutrop, Urmas (eds.), Teooria ja mudelid eluteaduses. Eesti NSV Teaduste Akadeemia, 215-220.

- 1990. Universe of the Mind: A semiotic Theory of Culture. London: I. B. Tauris.

Lotman, Mihhail 2002. Umwelt and semiosphere. Sign Systems Studies 30(1): $33-$ 40.

Merrell Floyd 1992. As signs grow, so life goes. In: Sebeok, Umiker-Sebeok 1992: 251-281.

- 1994. Of signs and life. Semiotica 101(3/4), 175-240.

- 1996. Signs Grow: Semiosis and Life Process. Toronto: University of Toronto Press.

- 1998. Does the life of signs yield a meaningful universe? Semiotica 120(3/4): 311-342.

- 1999. Living signs. Semiotica 127(1/4): 453-479.

Sebeok, Thomas A. 2001. Global Semiotics. Bloomington: Indiana University Press.

Sebeok, Thomas A.; Danesi, Marcel 2000. The Forms of Meaning: Modeling Systems Theory and Semiotic Analysis. Berlin: Mouton de Gruyter.

Sebeok, Thomas A.; Umiker-Sebeok, Jean (eds.) 1992. Biosemiotics: The Semiotic Web 1991. Berlin: Mouton de Gruyter.

Stjernfelt, Frederik 1992. Categorical perception as a general prerequisite to the formation of signs? On the biological range of a deep semiotic problem in Hjelmslev's as well as Peirce's semiotics. In: Sebeok, Umiker-Sebeok 1992: 427-454.

Torop, Peeter 1995. Total'nyj perevod. Tartu: Tartu University Press.

Uexküll, Jakob von 1907. Die Umrisse einer kommenden Weltanschauung. Die neue Rundschau 18: 641-661.

— 1928. Theoretische Biologie. Berlin: Julius Springer. 


\section{Знак не живой. Текст - живой}

В статье анализируется соотношение жизненного и знакового процессов, при этом подвергается критике их простое приравнивание. Исходя из положения, что организм (и его простейшая разновидность - клетка) является носителем качества, называемого “жизн”", в статье предпринимается попытка найти семиотическое соответствие свойству быть живым. Кандидатом на роль такого соответствия может быть текстуальный процесс как знак. Учитывая нелингвистичность биологических текстов, в биологии можно было бы заменить понятие "текст" на “биотекст".

\section{Märk ei ole elus. Tekst küll}

Artiklis analüüsitakse eluprotsessi ja märgiprotsessi mõistete vahekorda, kritiseerides nende lihtsat võrdsustamist. Eeldades, et organism (ja selle lihtsaim erijuht — rakk) on 'eluks' nimetatava kvaliteedi kandja, püütakse leida semiootilist vastet, mis oleks võrdsustatav elusolemise omadusega. Sellise vaste kandidaadiks võib olla tekstuaalne protsess kui mitmene märk. Silmas pidades bioloogiliste tekstide mittelingvistilisust, tuleks bioloogias kasutada bioteksti mõistet teksti asemel. 